\title{
Vitamin A deficiency induces morphometric changes and decreased functionality in chicken small intestine
}

\author{
Zehava Uni ${ }^{1}$, Gidi Zaiger ${ }^{1}$ and Ram Reifen ${ }^{2}$ \\ ${ }^{1}$ Department of Animal Science and ${ }^{2}$ School of Nutritional Sciences, Faculty of Agriculture, \\ Food and Environmental Quality Sciences, Hebrew University of Jerusalem, Rehovot, Israel
}

(Received 17 October 1997 - Revised 12 May 1998 - Accepted 13 May 1998)

\begin{abstract}
The effect of vitamin A on chicken intestinal mucosal morphology and functionality was tested in relation to severe and mild vitamin A deficiency and vitamin A repletion. Compared with rats and mice, chickens have a very quick response to a deficient dietary intake. Severe vitamin A deficiency altered the small intestine of chickens at both the biochemical and the morphological levels. It caused the loss of mucosal protein, reduced villus height and crypt depth and diminished activities of disaccharidases, transpeptidase and alkaline phosphate (EC 3.1.3.1). The ratios RNA:DNA, RNA:protein and protein:DNA, and the DNA concentrations in $1 \mathrm{~g}$ intestinal tissue, together with morphological measurements, provided knowledge about the pattern of lesion. The results indicated that (1) lack of vitamin A influenced cellular hyperplasia as it caused an increase in DNA content and in the number of enterocytes per villus; (2) lack of vitamin A influenced cellular hypertrophy as it decreased the protein:DNA ratio. There was no difference in mucosal enzyme activity between the two deficient groups. The repletion group exhibited a remarkable increase in mucosal enzyme activity only $4 \mathrm{~d}$ after switching to the control diet. The evidence presented in our paper suggests that the low vitamin A supply interferes with the normal activity of chicken intestinal mucosa as it influences the processes of proliferation and maturation of enterocytes.
\end{abstract}

Small intestine: Vitamin A: Chicken

In birds, vitamin A is supplied by the yolk in the embryonic state, and must be replaced by an exogenous source in the diet after hatching. Vitamin A deficiency is characterized in chickens by well-recognized signs including lack of growth, weakness, ruffled feathers, xerophthalmia, impaired egg production and poor hatchability, and lowered resistance of the bird to some poultry diseases (Aydelotte, 1963; Sklan et al. 1994). All these phenomena cause economic loss to the chicken industry. Although a feed may contain a level of vitamin A sufficient to fulfill normal growth requirements, there are several factors, such as mycotoxins (Osborne et al. 1982), reoviruses (Rosenberger, 1984), coccidial infections (Ruff \& Fuller, 1975) and nutritional imbalances (Marusich \& Bauernfeind, 1981), which may still cause vitamin A depletion.

The various external manifestations of vitamin A deficiency are secondary effects resulting from primary lesions at the cellular and molecular levels. The role that retinoicacid receptors play in regulating the expression of a variety of growth factors involved in cellular differentiation is well documented (Gudas et al. 1994). Changes in skin and in tracheal and cervical epithelia as a result of vitamin A deficiency in rats and mice have been extensively described (Rosenthal et al. 1994). Other publications describe mild changes in the jejunal structure and function in rats (Warden et al. 1996). However, the effect of vitamin A deficiency in chickens has not been described at a cellular or a molecular level in any epithelial tissue.

In chicks, the small intestine develops rapidly after hatching and thus requires vitamin A for this development. Intestinal growth at a young age is followed by increased villus volume, crypt depth and mucosal enzyme activity and is achieved initially by cellular hyperplasia, and afterwards by cellular hypertrophy (Uni et al. 1995, 1996, 1998).

Renewal of cells occurs by continuous division of a stemcell population located in the intestinal crypt (Chang \& Leblond, 1974). As enterocytes migrate toward the villus tip, they acquire differentiated functions, including the expression of brush-border enzymes such as disaccharidase, alkaline phosphatase (EC 3.1.3.1; AP) and transpeptidase (Maroux et al. 1973; Wieser, 1973; Semenza, 1986; Ferraris et al. 1992). These processes of rapid cell renewal and

Abbreviations: AP, alkaline phosphatase; C, control diet; $\gamma$-GT, $\gamma$-glutamyl transpeptidase; MDD, mildly vitamin A-deficient diet; REP, repletion group; SDD, severely vitamin A-deficient diet.

*Corresponding author: Dr Zehava Uni, fax +972 8945 763, email Uni@agri.huji.ac.il 
maturation are sensitive to vitamin A depletion (Zile et al. 1977; Rosenthal et al. 1994). Therefore we examined the effects of mild and severe vitamin A deficiency and vitamin A repletion on chicken intestinal morphology and growth, and on mucosal enzyme activity.

\section{Materials and methods}

\section{Animals and diets}

Arbor Acres male chicks were obtained from a commercial hatchery, weighed on reception, and those differing from the mean weight by $10 \%$ or more $(46 \pm 4.6 \mathrm{~g})$ were excluded. All birds were housed in a temperature-controlled brooder previously divided into eight pens of $2 \mathrm{~m}^{2}$. Eight groups of thirty chicks were randomly assigned to one of the four treatments (two replicates per treatment). The treatments were: (1) severely vitamin A-deficient diet (SDD), a soyabean meal-sorghum diet, formulated according to the nutrient requirements of the National Research Council (1994) but without vitamin A in the vitamin mix; (2) mildly vitamin A-deficient diet (MDD), with $250 \mu \mathrm{g}$ retinol acetate/kg diet; (3) control diet (C), with $450 \mu \mathrm{g}$ retinol acetate $/ \mathrm{kg}$ diet, according to the National Research Council (1994) recommendation for vitamin A concentration in the diet of broiler chickens. The fourth treatment group served as a repletion group (REP); it was fed on SDD from hatching, and was switched to diet $\mathrm{C}$ on day 24 .

Diets and water were supplied ad libitum. The lighting schedule consisted of $23 \mathrm{~h}$ light and $1 \mathrm{~h}$ dark. All birds were weighed from the day of hatching until $35 \mathrm{~d}$ of age. At $28 \mathrm{~d}$ of age, twenty chickens from each group were killed and organs were taken for analysis; the liver was taken for vitamin A determination and the jejunum was taken for histological and morphometric analysis, mucosal enzyme activity measurement and determination of DNA, RNA and protein per $g$ wet jejunal tissue. All procedures were approved by the Animal Care and Ethics Committee, The Hebrew University of Jerusalem.

\section{Tissue sampling}

Twenty animals were randomly chosen from each of the eight groups and killed at $28 \mathrm{~d}$ of age with an intracardiac overdose of sodium pentobarbital $(0 \cdot 2 \mathrm{~g} / \mathrm{kg})$. In each animal the small intestine, from the end of the duodenum up to Meckel's diverticulum, was removed. Segments $(30 \mathrm{~mm}$ long) were taken from the middle of the section, flushed with cold PBS, divided into three smaller segments and placed in three separate tubes: (1) stored at $-20^{\circ}$ until analysed for enzyme activities; (2) fixed in $100 \mathrm{ml} / \mathrm{l}$ neutral buffered formalin solution for histology and morphometric analysis; (3) frozen in liquid $\mathrm{N}_{2}$ and then stored at $-80^{\circ}$ until analysed for RNA, DNA and protein content. The liver was removed from each bird and the left lobe was stored at $-80^{\circ}$ until analysis.

\section{Vitamin A analysis}

Vitamin A levels were determined by reversed-phase HPLC on a reverse phase $C_{18}$ column using retinol acetate as internal standard and fluorescence detection (Sklan \& Halevy, 1984).

\section{Histology}

Jejunum sections from SDD and $\mathrm{C}$ groups were fixed in $100 \mathrm{ml} / 1$ neutral buffered formalin, embedded in paraffin, sectioned, stained with haematoxylin and eosin and examined by light microscopy. Morphometric indices were determined using computer analysis (Photoshop 4.0, Adobe System Incorporation, CA, USA and NIH Image, Bethesda, MD, USA). The morphometric variables analysed included villus height (from the tip of the villus to the villus-crypt junction), crypt depth (defined as the depth of the invagination between adjacent villi), villus width (defined as the width at half height) and number of enterocyte cells per $\mu \mathrm{m}$ villus. Values are means from ten well-oriented crypt villus units per section.

\section{Mucosal enzyme activity}

Enzyme activity was assayed in homogenized smallintestine tissue $(50 \mathrm{mg}$ tissue $/ \mathrm{ml}$ saline): sucrase (EC 3.2.1.48) and maltase (EC 3.2.1.20) activities were assayed colorimetrically by using sucrose and maltose respectively, as substrates (Dahlquist, 1964; Palo et al. 1995). Activity is expressed as mmol glucose released/min. AP activity was determined by measuring the hydrolysis of $p$-nitrophenol spectrophotometrically (Sigma kit 104, Sigma Chemical Co., St Louis, MO, USA; Palo et al. 1995). One unit of AP activity is defined as the amount of enzyme necessary to release $1 \mu \mathrm{mol} p$-nitrophenol in $1 \mathrm{~min}$. Results are expressed as units of activity. Activity of $\gamma$-glutamyl transpeptidase (EC 2.3.2.2; $\gamma$-GT) was determined using L- $\gamma$-glutamyl-3-carboxy-4-nitroanilide as substrate (Sigma kit 419, Sigma Chemical Co.; D'Argenio et al. 1989). One unit of $\gamma$-GT activity is defined as the amount of enzyme that will catalyse the formation of $1 \mu \mathrm{mol} 5$-amino2-nitrobenzoate/min. Results are expressed as units of activity.

\section{RNA, DNA and protein content}

The RNA, DNA and protein were extracted from the intestinal segments using TRI REAGENT ${ }^{\circledR}$-RNA/DNA/ Protein isolation reagent (Molecular Research Center Inc., $\mathrm{OH}$, USA). The tissue was homogenized in TRI REAGENT $(1 \mathrm{ml} / 100 \mathrm{mg}$ tissue) using a glass-Teflon homogenizer. The homogenate was left for $5 \mathrm{~min}$ at room temperature and then chloroform $(0.2 \mathrm{ml} / \mathrm{ml}$ TRI REAGENT) was added. Following centrifugation $(12000 \mathrm{~g}$ for $15 \mathrm{~min}$ at $4^{\circ}$ ), the mixture was separated into three phases: the upper aqueous phase which included RNA, the interphase which included DNA and the bottom phase which included proteins. RNA, DNA and proteins were isolated from each phase according to the procedure recommendations. Quantities of RNA, DNA and proteins were determined colorimetrically. Results are expressed as $\mathrm{mg} / \mathrm{g}$ wet intestinal tissue. 


\section{Statistical analysis}

Data were analysed by ANOVA using the General Linear Models procedure of Statistical Analysis Systems (1986). The model included the main effects of groups, animals within group, dietary treatment, and residual error term. There was no effect of grouping, therefore the main effects were reduced to chicken, treatment and residual error term. Comparison of treatment means was done by contrast $t$ test, and values were considered statistically different at $P<0.05$. Results are reported as means with their standard errors.

\section{Results}

\section{Retinol levels and body weight}

Vitamin A concentration in the liver was $58.8 \mu \mathrm{g} / \mathrm{g}$ at $28 \mathrm{~d}$, in chickens fed on diet C. However, feeding diets which

Table 1. Hepatic retinol concentrations $(\mu \mathrm{g} / \mathrm{g}$ wet tissue) in 28-d-old chickens fed to induce severe deficiency of vitamin $A$ (SDD) or mild deficiency of vitamin $A(M D D)$, repleted with vitamin A following deficiency (REP), or fed on a control diet (C)

(Mean values with their standard errors for forty chickens)

\begin{tabular}{lcc}
\hline & \multicolumn{2}{c}{ Hepatic retinol $(\mu \mathrm{g} / \mathrm{g})$} \\
\cline { 2 - 3 } Group & Mean & SE \\
\hline SDD & $0.5^{\mathrm{a}}$ & $0 \cdot 1$ \\
MDD & $2 \cdot 1^{\mathrm{b}}$ & $0 \cdot 6$ \\
REP & $56 \cdot 6^{\mathrm{c}}$ & 48 \\
C & $58 \cdot 8^{\mathrm{c}}$ & 25 \\
\hline
\end{tabular}

a,b.c Mean values bearing different superscript letters were significantly different, $P<0.05$. induced mild and severe deficiency of vitamin A resulted in very low hepatic vitamin A levels of 2.1 and $0.5 \mu \mathrm{g} / \mathrm{g}$ respectively (Table 1).

A decrease of growth rate $(P<0.05)$ was observed in the two vitamin A-deficient groups after $18 \mathrm{~d}$ on the experimental diets. From day 24, weight loss was observed in the group receiving SDD, while the group fed on MDD continued to grow slowly. On repletion (REP), body weight increased, starting $4 \mathrm{~d}$ after changing diets, although body weight was still significantly lower than in the control group (Fig. 1).

\section{$R N A, D N A$ and protein contents in $1 \mathrm{~g}$ jejunal tissue}

High DNA and lower RNA concentrations were found in the SDD group than in the $C$ and REP groups $(P<0.5)$. Protein content was higher in the $C$ group than in the SDD, MDD and REP groups $(P<0.05)$. The RNA:DNA ratio, which indicates tissue activity, and the RNA:protein ratio, which indicates ribosomal capacity, were lower $(P<0.05)$ in the SDD group than in all other groups. Protein:DNA ratios, which reflect cell size, were lower in the two deficient groups than in the REP and $\mathrm{C}$ groups $(P<0.05)$ (Table 2).

\section{Morphometry of jejunal tissue}

The jejunal morphology was influenced by the vitamin A-deficient diet (Table 3; Fig. 2); villus height was significantly lower in chickens fed on a deficient diet and villus width was greater than in the $\mathrm{C}$ group $(P<0.05)$. The number and density of enterocytes observed in the SDD group were higher than in the control group $(P<0.05)$.

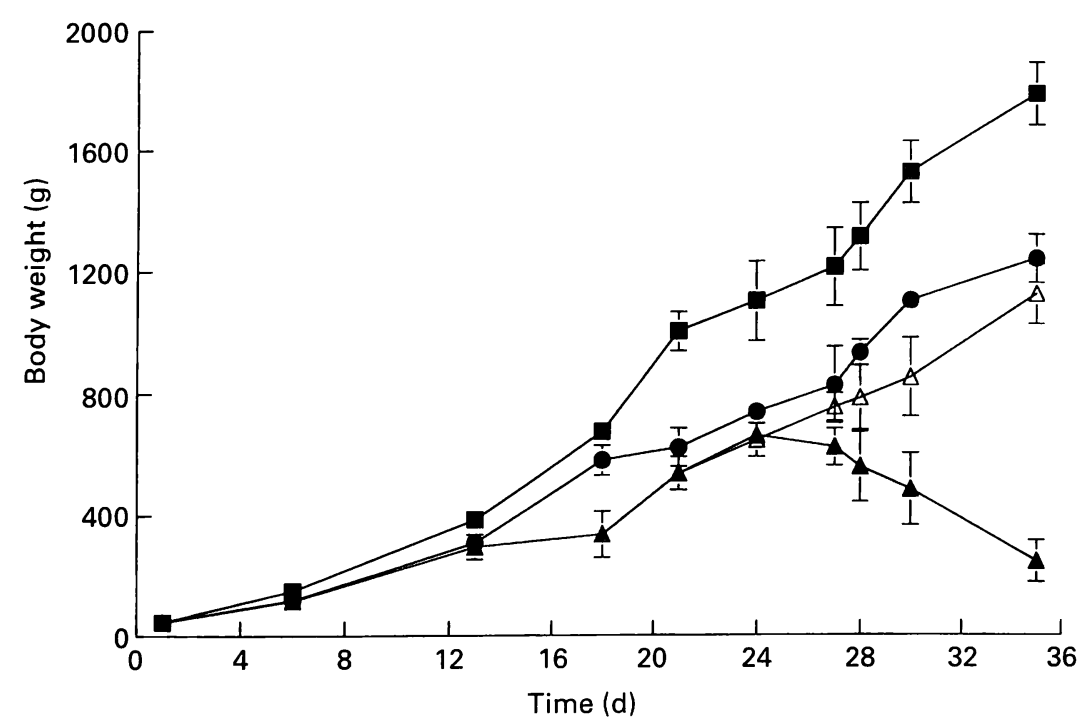

Fig. 1. Body weights of chickens fed to induce severe deficiency of vitamin $A(\Delta)$ or mild deficiency of vitamin $A(\bullet)$, repleted with vitamin $A$ following deficiency $(\triangle)$ or fed on a control diet $(\square)$. Values are means with their standard errors for forty animals per treatment on days $1-28$ and twenty animals per treatment on days 30 and 35. A few standard errors were small and have been obscured by the symbols. 
Table 2. Concentrations and ratios of DNA, RNA and protein in $1 \mathrm{~g}$ wet jejunal tissue in chickens fed to induce severe deficiency of vitamin $A(S D D)$ or mild deficiency of vitamin A (MDD), repleted with vitamin A following deficiency (REP), or fed on a control diet (C)

(Mean values with their standard errors for forty chickens)

\begin{tabular}{|c|c|c|c|c|c|c|c|c|}
\hline & \multicolumn{2}{|c|}{ SDD } & \multicolumn{2}{|c|}{ MDD } & \multicolumn{2}{|c|}{ REP } & \multicolumn{2}{|c|}{ C } \\
\hline & Mean & SE & Mean & SE & Mean & SE & Mean & $S E$ \\
\hline $\begin{array}{l}\text { RNA }(\mathrm{mg} / \mathrm{g}) \\
\text { DNA }(\mathrm{mg} / \mathrm{g}) \\
\text { Protein }(\mathrm{mg} / \mathrm{g}) \\
\text { RNA: DNA } \\
\text { Protein: DNA } \\
\text { RNA: Protein }\end{array}$ & $\begin{array}{c}4 \cdot 1^{\mathrm{a}} \\
25 \cdot 1^{\mathrm{b}} \\
160 \cdot 1^{\mathrm{a}} \\
0 \cdot 14^{\mathrm{a}} \\
6 \cdot 52^{\mathrm{a}} \\
0.025^{\mathrm{a}}\end{array}$ & $\begin{array}{c}1 \cdot 1 \\
3 \cdot 0 \\
26 \cdot 3 \\
0 \cdot 12 \\
1 \cdot 15 \\
0.003\end{array}$ & $\begin{array}{c}5 \cdot 2^{\mathrm{b}} \\
25 \cdot 1^{\mathrm{b}} \\
154 \cdot 2^{\mathrm{a}} \\
0.21^{\mathrm{b}} \\
6.60^{\mathrm{a}} \\
0.034^{\mathrm{b}}\end{array}$ & $\begin{array}{c}1 \cdot 1 \\
3 \cdot 3 \\
19 \cdot 1 \\
0.11 \\
1.16 \\
0.002\end{array}$ & $\begin{array}{c}6.0^{b} \\
21.0^{a} \\
160.1^{a} \\
0.29^{b} \\
7.57^{b} \\
0.040^{b}\end{array}$ & $\begin{array}{c}2 \cdot 0 \\
2 \cdot 1 \\
17 \cdot 3 \\
0.10 \\
0.31 \\
0.003\end{array}$ & $\begin{array}{c}5 \cdot 2^{\mathrm{b}} \\
21 \cdot 1^{\mathrm{a}} \\
296 \cdot 3^{\mathrm{b}} \\
0.24^{\mathrm{b}} \\
7 \cdot 20^{\mathrm{b}} \\
0.036^{\mathrm{b}}\end{array}$ & $\begin{array}{c}1 \cdot 1 \\
2 \cdot 0 \\
30 \cdot 3 \\
0.12 \\
1.30 \\
0.003\end{array}$ \\
\hline
\end{tabular}

a,b,c Mean values within a row bearing different superscript letters were significantly different, $P<0.05$.

Table 3. Morphological measurements in the small intestine of chickens fed to induce severe deficiency of vitamin A (SDD) or fed on a control diet (C)

(Values are means with their standard errors from ten crypt-villus units per section from five different animals per treatment group)

\begin{tabular}{|c|c|c|c|c|}
\hline & \multicolumn{2}{|c|}{ SDD } & \multicolumn{2}{|c|}{ C } \\
\hline & Mean & $\mathrm{SE}$ & Mean & $\mathrm{SE}$ \\
\hline $\begin{array}{l}\text { Villus height }{ }^{\star}(\mu \mathrm{m}) \\
\text { Villus width } \dagger(\mu \mathrm{m}) \\
\text { Crypt depth } \ddagger(\mu \mathrm{m}) \\
\text { Number of enterocytes in one villus } \\
\text { Enterocyte density§ }\end{array}$ & $\begin{array}{c}478^{a} \\
138^{b} \\
175^{a} \\
1080^{b} \\
2 \cdot 21^{b}\end{array}$ & $\begin{array}{r}55 \\
27 \\
24 \\
305 \\
0.52\end{array}$ & $\begin{array}{l}612^{\mathrm{b}} \\
111^{\mathrm{a}} \\
188^{\mathrm{a}} \\
848^{\mathrm{a}} \\
1.34^{\mathrm{a}}\end{array}$ & $\begin{array}{c}61 \\
16 \\
25 \\
189 \\
0.13\end{array}$ \\
\hline
\end{tabular}

a,b Mean values within a row bearing different superscript letters were significantly different, $P<0.05$.

"From the tip of the villus to the villus-crypt junction.

$\dagger$ Defined as the depth of the invagination between adjacent villi.

$\ddagger$ Defined as the width at half height.

$\S$ Number of enterocyte cells per $\mu \mathrm{m}$ villus.

\section{Mucosal enzyme activity}

Disaccharidase activity per $\mathrm{g}$ tissue (Table 4 ) tended to be lower in the SDD and MDD groups than in the $C$ and REP groups. However, when maltase and sucrase activities were expressed relative to DNA, a significantly lower level of activity was found in the two deficient groups.

The levels of AP activity were lower $(P<0.05)$ both per $\mathrm{g}$ tissue and per mg DNA in the SDD and MDD groups than in either REP or C (Table 5). The level of $\gamma$-GT activity expressed per $\mathrm{g}$ tissue and per mg DNA was lower $(P<0.05)$ in the SDD group than in the REP and $C$ groups.

\section{Discussion}

The meat-type chicken is a good model for studying phenomena related to deficient diets, since deficiency occurs rapidly. Compared with rats and mice (Zile et al. 1977; McLaren, 1978) a relatively short time is required to obtain a vitamin A-deficient animal. This fact may be due to the rapid growth of the chicken, which multiplies its body weight by forty-eight times in $42 \mathrm{~d}$ (National Research Council, 1994). After $28 \mathrm{~d}$ on the deficient diet, vitamin A stores in the liver of the SDD group were depleted. This is in agreement with the findings of Sklan et al. (1994) who reported low levels of retinol in the liver and plasma of chickens after $21 \mathrm{~d}$ on vitamin A-deficient diets.

The immediate effect of vitamin A on chicken growth is closely associated with the role the vitamin plays in the maintenance of normal proliferation and differentiation in various epithelial tissues. Severe vitamin A deficiency was found to alter the small intestine of the chicken, at both the biochemical and the morphological levels, reducing mucosal thickness and villus height, and diminishing activities of disaccharidases, $\gamma$-GT and AP. This was accompanied by a level of protein that was significantly lower in the SDD, MDD and REP groups than in the C group.

Protein synthesis rate depends on the number of ribosomes per cell and the activity of these ribosomes during the process of translation of RNA into protein. The RNA: protein ratio has been proposed by Waterlow et al. (1978) as an index for ribosomal capacity. Using this index here indicated a significantly lower ribosomal capacity in the SDD group than in the other groups. The findings suggest that the overall process of protein synthesis in the small intestine was impaired as a result of vitamin A deficiency.

The results of this experiment indicated an effect of vitamin A on enterocyte proliferation. Zile et al. (1977) and Higachi \& Wang (1995) demonstrated a correlation between vitamin A concentration and enterocyte proliferation in the small intestine of the rat and in a colonic epithelial cell line. The significantly higher DNA content which was found in SDD and MDD groups compared with the REP and $C$ groups may suggest a higher number of cells caused by a higher proliferation rate. 

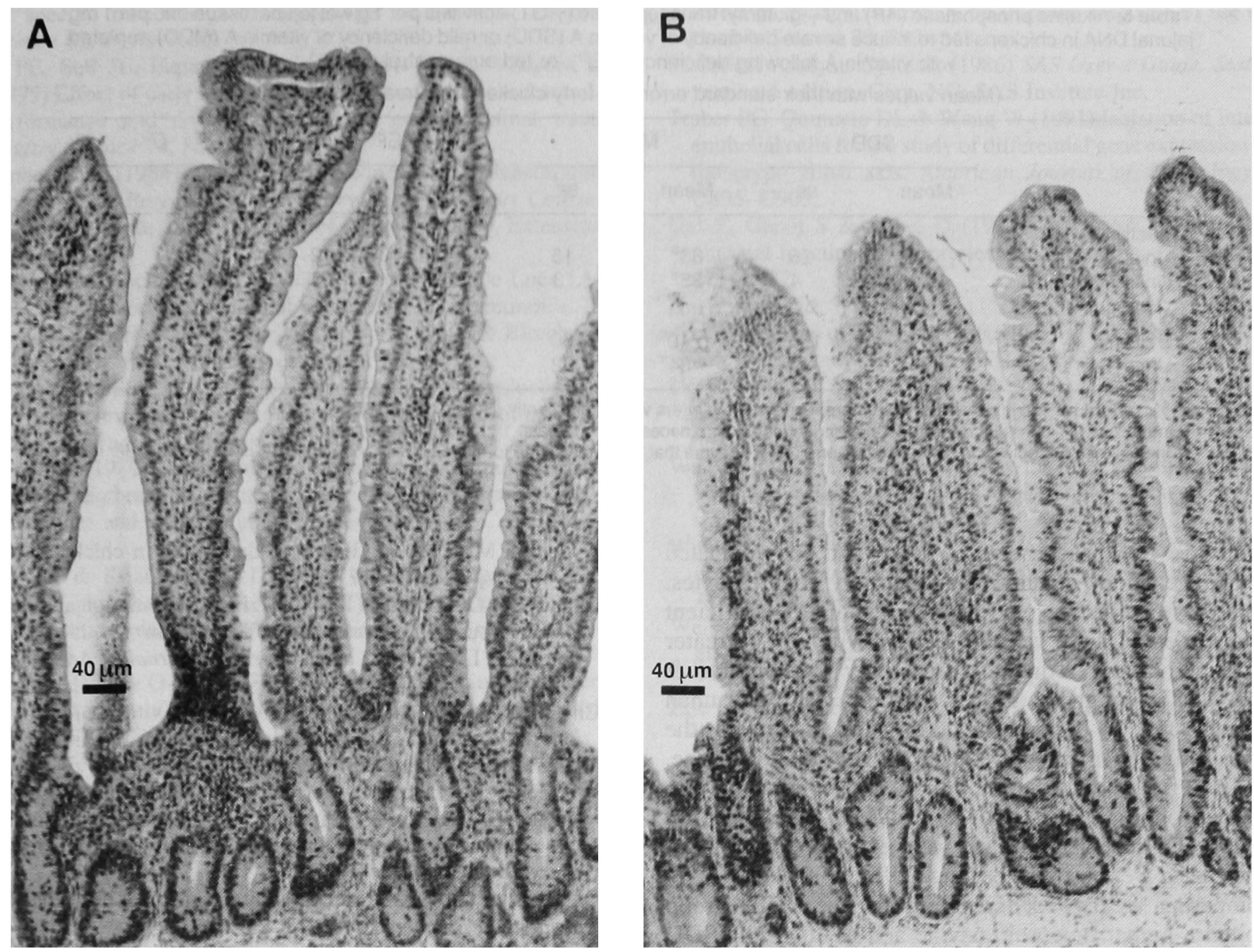

Fig. 2. Light micrograph $(\times 100)$ of intestinal villi from the jejunum of chickens fed on a control diet $(A)$ and from chickens fed to induce severe deficiency of vitamin A (B). Haematoxylin-eosin; bar $=40 \mu \mathrm{m}$.

Table 4. Disaccharidase activity ${ }^{\star}$ per $1 \mathrm{~g}$ wet jejunal tissue and per $1 \mathrm{mg}$ jejunal DNA in chickens fed to induce severe deficiency of vitamin $A(S D D)$ or mild deficiency of vitamin A (MDD), repleted with vitamin A following deficiency (REP), or fed on a control diet (C) (Mean values with their standard errors for forty chickens per treatment group)

\begin{tabular}{|c|c|c|c|c|c|c|c|c|}
\hline & \multicolumn{2}{|c|}{ SDD } & \multicolumn{2}{|c|}{ MDD } & \multicolumn{2}{|c|}{ REP } & \multicolumn{2}{|c|}{ C } \\
\hline & Mean & SE & Mean & SE & Mean & SE & Mean & SE \\
\hline $\begin{array}{l}\text { Sucrase activity } \\
\text { mmol glucose/g per min } \\
\text { mmol glucose/mg DNA per min }\end{array}$ & $\begin{array}{r}120^{\mathrm{a}} \\
48^{\mathrm{a}}\end{array}$ & $\begin{array}{r}34 \\
5\end{array}$ & $\begin{array}{r}129^{\mathrm{a}} \\
51^{\mathrm{a}}\end{array}$ & $\begin{array}{r}21 \\
6\end{array}$ & $\begin{array}{r}149^{\mathrm{a}} \\
70^{\mathrm{b}}\end{array}$ & $\begin{array}{r}24 \\
6\end{array}$ & $\begin{array}{r}156^{\mathrm{a}} \\
74^{\mathrm{b}}\end{array}$ & $\begin{array}{r}35 \\
7\end{array}$ \\
\hline $\begin{array}{l}\text { Maltase activity } \\
\mathrm{mmol} \text { glucose/g per min } \\
\mathrm{mmol} \text { glucose/mg DNA per min }\end{array}$ & $\begin{array}{l}758^{\mathrm{a}} \\
303^{\mathrm{a}}\end{array}$ & $\begin{array}{r}181 \\
42\end{array}$ & $\begin{array}{l}897^{\mathrm{a}} \\
358^{\mathrm{a}}\end{array}$ & $\begin{array}{r}224 \\
35\end{array}$ & $\begin{array}{r}1139^{\mathrm{a}} \\
542^{\mathrm{b}}\end{array}$ & $\begin{array}{r}177 \\
67\end{array}$ & $\begin{array}{l}944^{\mathrm{a}} \\
449^{\mathrm{b}}\end{array}$ & $\begin{array}{r}224 \\
40\end{array}$ \\
\hline
\end{tabular}

a,b Mean values within a row bearing different superscript letters were significantly different, $P<0.05$.

*Activity is expressed as mmol glucose released per $1 \mathrm{~min}$.

The effect of vitamin A level on the processes of hypertrophy and hyperplasia in the jejunal tissue was also exhibited by the lower RNA:DNA ratio and protein:DNA ratio in the vitamin A-deficient groups compared with the REP and $\mathrm{C}$ groups.

In rodents, vitamin A deficiency has not been found to cause any morphological alteration in the intestine (Ahmed et al. 1990), whereas moderate changes in the jejunal structure were found in rats (Warden et al. 1996). In the present study, vitamin A-deficient mucosa in chickens exhibited structural abnormality: the mucosa had reduced villus height, increased villus width and reduced enterocyte size.

It has been established that mature and active enterocytes express disaccharidase and AP activities (Wieser, 1973; Traber et al. 1991). In our present study, the reduction in 
Table 5. Alkaline phosphatase (AP) and $\gamma$-glutamyl transpeptidase $(\gamma$-GT) activities per $1 \mathrm{~g}$ wet jejunal tissue and per $1 \mathrm{mg}$ jejunal DNA in chickens fed to induce severe deficiency of vitamin A (SDD) or mild deficiency of vitamin A (MDD), repleted with vitamin A following deficiency (REP), or fed on a control diet (C)

(Mean values with their standard errors for forty chickens per treatment group)

\begin{tabular}{|c|c|c|c|c|c|c|c|c|}
\hline & \multicolumn{2}{|c|}{ SDD } & \multicolumn{2}{|c|}{ MDD } & \multicolumn{2}{|c|}{ REP } & \multicolumn{2}{|c|}{$C$} \\
\hline & Mean & SE & Mean & SE & Mean & SE & Mean & $\mathrm{SE}$ \\
\hline $\begin{array}{l}\text { AP activity } \\
\text { Units } / g \\
\text { Units } / \text { mg DNA }\end{array}$ & $\begin{array}{l}84^{\mathrm{a}} \\
33^{\mathrm{a}}\end{array}$ & $\begin{array}{r}26 \\
4\end{array}$ & $\begin{array}{l}88^{a} \\
35^{a}\end{array}$ & $\begin{array}{r}16 \\
3\end{array}$ & $\begin{array}{r}144^{\mathrm{b}} \\
68^{\mathrm{c}}\end{array}$ & $\begin{array}{r}12 \\
6\end{array}$ & $\begin{array}{r}116^{\mathrm{b}} \\
55^{\mathrm{b}}\end{array}$ & $\begin{array}{r}24 \\
4\end{array}$ \\
\hline $\begin{array}{l}\gamma \text {-GT activity } \\
\text { Units } t / g \\
\text { Units } t / m g \text { DNA }\end{array}$ & $\begin{array}{r}1110^{\mathrm{a}} \\
444^{\mathrm{a}}\end{array}$ & $\begin{array}{r}150 \\
42\end{array}$ & $\begin{array}{r}1210^{\mathrm{a}} \\
484^{\mathrm{a}}\end{array}$ & $\begin{array}{r}160 \\
52\end{array}$ & $\begin{array}{r}1510^{b} \\
719^{b}\end{array}$ & $\begin{array}{r}230 \\
74\end{array}$ & $\begin{array}{r}1790^{\mathrm{b}} \\
852^{\mathrm{b}}\end{array}$ & $\begin{array}{r}320 \\
90\end{array}$ \\
\hline
\end{tabular}

a,b,c Mean values within a row bearing different superscript letters were significantly different, $P<0.05$.

* One unit of AP activity is defined as the amount of enzyme necessary to release $1 \mu \mathrm{mol} p$-nitrophenol in $1 \mathrm{~min}$

† One unit of $\gamma$-GT activity is defined as the amount of enzyme that will catalyse the formation of $1 \mu \mathrm{mol} 5$-amino-2-nitrobenzoate per min.

the activities of disaccharidase, $\gamma$-GT and AP indicated some changes in the maturation and activity of enterocytes. Studies of mucosal enzyme content in vitamin A-deficient rats have yielded quite variable results, with either greater enzyme activity or reduction in activity (Majumdfar \& Ghosh, 1987; Singh \& Krishnakantha, 1987; Chauhan \& Kansal, 1989). However, these studies assayed the enzyme activities in the entire length of the small intestine, in contrast to our study, in which measurements were performed on $1 \mathrm{~g}$ tissue, midway between the duodenum and Meckel's diverticulum, and were expressed as units of activity per $g$ wet tissue or per mg DNA.

Comparing the two deficient groups, the MDD group exhibited a higher mucosal enzyme activity than the SDD group on day 28 , and MDD animals maintained a low rate of growth while SDD animals lost weight dramatically. These results demonstrate dose response.

The REP group exhibited rapid recovery: only $4 \mathrm{~d}$ after switching to the $\mathrm{C}$ diet, the concentration of hepatic retinol was similar to that of the control group, although variations between the animals were large. Sucrase and $\gamma$-GT activities per mg DNA were significantly higher in the REP group than in the SDD and MDD groups. This, and the significant increase in AP activity, which was even higher than the activity found in the $C$ group, suggest that repletion with vitamin $\mathrm{A}$ induced maturation of the enterocytes during the short period of a few days.

The evidence presented in this paper suggests that the absence of vitamin A interferes with the normal processes of chicken intestinal mucosa development, as it influences proliferation, growth and maturation of enterocytes. Administration of higher doses of vitamin A during an intestinal disease may have a positive effect on damaged mucosa, and may lead to a rapid recovery of mucosal functions.

\section{Acknowledgement}

This work was supported in part by the Vigivani Foundation.

\section{References}

Ahmed F, Jones DB \& Jackson AJ (1990) The interaction of vitamin A deficiency and rotavirus infection in the mouse. British Journal of Nutrition 63, 363-373.
Aydelotte MB (1963) Vitamin A deficiency in chickens. British Journal of Nutrition 17, 205-211.

Chang H \& Leblond CP (1974) Origin, differentiation and renewal of the four main epithelial cell types in the mouse small intestine. I. Columnar cell. American Journal of Anatomy 141, 461-480.

Chauhan MJ \& Kansal VK (1989) Effect of vitamin A deficiency on rat intestinal digestive and absorptive functions. Indian Journal of Medical Research 90, 448-452.

D'Argenio G, Ciacci C, Sorrentini I, Mattera D, Cosenza V, Iovino P, Gatto A \& Mazzacca G (1989) Behavior of transglutaminase activity in intestine of starved and refed rats. Enzyme 42, 61-70.

Dahlquist A (1964) Method of assay of intestinal disaccharidases. Analytical Biochemistry 7, 18-25.

Ferraris RP, Villenas SA \& Diamond J (1992) Regulation of brush border enzyme activities and enterocyte migration rates in mouse small intestine. American Journal of Physiology 262, G1047-G1059.

Gudas LJ, Sporn MB \& Roberts AB (1994) Cellular biology and biochemistry of the retinoids. In The Retinoids, 2nd ed., pp. 443-520 [MB Sporn, AB Roberts and DS Goodman, editors]. New York, NY: Academic Press.

Higuchi CM \& Wang W (1995) Comodulation of polyamines and proliferation: biomarker application to colorectal muscosa. Journal of Cellular Biochemistry 57, 256-261.

McLaren DS (1978) Nutritional deficiencies in animals and man: vitamin A. In CRC Handbook Series in Nutrition and Food, Section E: Nutritional Disorders, vol. III, Effect of Nutrient Deficiencies in Man, pp. 107-116 [M Rechcigl, editor]. Boca Raton, FL: CRC Press.

Majumdfar M \& Ghosh AK (1987) Effect of vitamin A deficiency on blood glucose level and intestinal disaccharidases activity. Indian Journal of Medical Research 86, 511-515.

Maroux S, Louvard D \& Baratti J (1973) The aminopeptidase from hog intestinal brush border. Biochimica et Biophysica Acta 321, 282-295.

Marusich WL \& Bauernfeind JC (1981) Oxycarotenoids in poultry feeds. In Carotenoids as Colorants and Vitamin A Precursors, pp. 319-462 [JC Bauernfeind, editor]. New York, NY: Academic Press.

National Research Council (1994) Nutrient Requirements for Poultry, 9th revised ed., pp. 19-34. Washington, DC: National Academy Press.

Osborne DJ, Huff WE, Hamilton PB \& Burmeister HR (1982) Comparison of ochratoxin, aflatoxin and T-2 toxin for their effects on selected parameters related to digestion and evidence 
for specific metabolism of carotenoids in chickens. Poultry Science 61, 1646-1652.

Palo PE, Sell JL, Piquer FJ, Soto-Salanova MF \& Vilaseca L (1995) Effect of early nutrient restriction on broiler chickens: 1. Performance and development of the gastrointestinal tract. Poultry Science 74, 88-101.

Rosenberger J (1984) The role of reoviruses in malabsorption syndrome. In Proceedings of Poultry Nutrition Short Course, pp. 1-5. Newark, DE: University of Delaware Coop. Extension Service.

Rosenthal D, Lancillotti F, Darwich N, Sinha R \& De Luca LM (1994) Regulation of epithelial differentiation by retinoids. In Vitamin $A$ in Health and Disease, pp. 425-440 [R Blomhoff, editor]. New York, NY: Marcel Dekker Inc.

Ruff MD \& Fuller HL (1975) Some mechanisms of reduction of carotenoid levels in chickens infected with E. acervulina or E. tenella. Journal of Nutrition 105, 1447-1456.

Semenza G (1986) Anchoring and biosynthesis of stalked brush border membrane protein: glycosidases and peptidases of enterocytes and of renal tubuli. Annual Review of Cell Biology 2. 255-313.

Singh RK \& Krishnakantha TP (1987) Intestinal epithelial cell alkaline phosphatase and $\mathrm{Na}^{+} \mathrm{K}^{+}$ATPase activities in albino rats in retinol deficiency. Nutrition Reports International 35, 973-980.

Sklan D \& Halevy O (1984) Vitamin A metabolism in chick liver: some properties of the cytosolic lipid-protein aggregate. British Journal of Nutrition 52, 107-114.

Sklan D, Melamed D \& Friedman A (1994) The effect of varying levels of dietary vitamin A on immune response in the chick. Poultry Science 73, 843-847.

Statistical Analysis Systems (1986) SAS User's Guide, Statistics, version 6 edition. Cary, NC: SAS Institute Inc.

Traber PG, Gumucio DL \& Wang W (1991) Isolation of intestinal epithelial cells for the study of differential gene expression along the crypt-villus axis. American Journal of Physiology 260, G895-G903.

Uni Z, Ganot S \& Sklan D (1998) Post hatch development of mucosal function in the broiler small intestine. Poultry Science 77, 75-82.

Uni Z, Noy Y \& Sklan D (1995) Post hatch changes in morphology and function of the small intestines in heavy and light strain chicks. Poultry Science 74, 1622-1629.

Uni Z, Noy Y \& Sklan D (1996) Developmental parameters of the small intestines in heavy and light strain chicks pre- and posthatch. British Poultry Science 36, 63-71.

Warden RA, Strazzari MJ, Dunkley PR \& O’Loughlin EV (1996) Vitamin A-deficient rats have only mild changes in jejunal structure and function. Journal of Nutrition 126, 1817-1826.

Waterlow JC, Garlick PJ \& Millward DJ (1978) Protein Turnover in Mammalian Tissues in the Whole Body, pp. 529-594. Amsterdam: North-Holland.

Weiser MM (1973) Intestinal epithelial cell surface membrane glycoprotein synthesis. Journal of Biological Chemistry 248, 2536-2541.

Zile M, Bunge EC \& De Luca HF (1977) Effect of vitamin A deficiency on intestinal cell proliferation in the rat. Journal of Nutrition 107, 552-560. 